\title{
National Identity in Mahmoud Darwish's Poetry
}

\author{
Khalil Hasan Nofal ${ }^{1}$ \\ ${ }^{1}$ Department of English Language and Literature, Faculty of Arts, Philadelphia University, Jordan \\ Correspondence: Khalil Hasan Nofal, Department of English Language and Literature, Faculty of Arts, \\ Philadelphia University, Jordan. E-mail: nofalk48@gmail.com
}

$\begin{aligned} & \text { Received: May 18, } 2017 \\ & \text { Accepted: August 21, } 2017 \quad \text { Online Published: August 30, } 2017 \\ & \text { doi:10.5539/ells.v7n3p66 }\end{aligned} \quad$ URL: http://doi.org/10.5539/ells.v7n3p66

\begin{abstract}
This paper is intended to examine the concept of national identity and how it is quested and portrayed in Mahmoud Darwish's poetry. The paper explores Darwish's quest for identity through different phases: language, homeland, roots and ancerstors, belonging, nature, culture, traditions, and exile. Palestine for Darwish is not only an origin or homeland, but it is an identity. Darwish adds some themes connected with the concept of homeland illustrated by references or images of mother, geography, history, farming, and folkloric heritage. Besides, identity for Darwish is three- dimensional: Palestinian, national, and human.
\end{abstract}

Keywords: identity, roots, language, homeland, heritage, culture, traditions, exile

\section{Introduction}

Identity can be generally defined as a set of distinct personal and behavioral characteristics, attributes, beliefs, and desires that define an individual as a member of a certain group. That is, your identity can be closely related to your beliefs and values and how you may see and respond to the world, i.e., your ideology. Moreover, identity can be glossed as the aspects or attributes of a person that form the basis of his / her dignity, honor, and pride. Put it differently, identity is one's feeling about one's self, character, goals and origins.

National identity is a concept that refers to a national group. It depends on different factors: country, origin, residence, ethnic or religious affiliation, and notions of affinity with one's nationality. Nationality, of course, can be different from the identity the person chooses for him / herself in regard to a given nation or country.

Mahmoud Darwish is one of the most prominent Palestinian poets. Most of his poetry is centered on his homeland, Palestine. Palestine for Darwish is not only origion or homeland but it is his identity. Darwish is the greatest national poet of Palestine. He is the poet of anger, longing, and hope. The aim of this paper is to critically investigate and scrutinize how national identity is quested and portrayed in Darwish's poetry. The paper attempts to analyze some of Darwish's poems that address home, language, culture, nature, exile, among others, that all express identity. That is how people feel while they are detached from their homes and families searching for their identities and home. The paper also expresses the influence of Darwish's words in expressing homesickness, homeliness and how the Palestinian people find their life away from their homeland, Palestine.

\section{National Identity in Poetry}

The quest for identity is an important aspect of poetry. Identity is "people's concept of who they are, of what sort of people they are, and how they relate to others" (Hogg \& Abrams, 1988, p. 2). Deng (1995, p. 1) maintains that national identity "is used to describe the way people define themselves and how they are defined by others on the basis of race, ethnicity , religion, language and culture". An answer to the question "what is identity?" may be how one answers the question "who are you?" or my identity is how I define who I am. See Hopf (1998, p. 175). The following poem illustrates this idea.

\section{I'm Nobody! Who Are You? Emily Dickinson \\ I'm Nobody! Who are you? \\ Are you-Nobody-Too? \\ Then there's a pair of us! \\ Don't tell! They'd advertise-you know!}


How dreary-to be-Somebody!

How public - like a Frog-

To tell one's name - the livelong June-

To an admiring Bog!

Identity is portrayed in poetry through a variety of symbolic resources, particularly language, land, origin, goals, beliefs, desires, attitudes, values, culture, nature, and heritage among others. National identity "describes that condition in which a mass of people have made the same identification with national symbols have internalized the symbols of the nation" (Bloom, 1990, p. 52). This idea can be clearly portrayed in the following poem.

\section{A Poem By: \\ The Lybian Poet—Rudiana Al-Fila}

\section{He snatched my identity card}

To make sure I was Arab

And started rummaging through my bag

As if I was carrying an atomic bomb.

Silently he stood staring at me.

A dark-skinned woman with revolutionary features.

I wondered why he asked about identity.

And why he didn't recognize that I was an Arab from my eyes.

Or he preferred I were a non- Arab.

So that I could enter his country without showing an identity card.

I waited for long as if I were not in Arab country.

I told him my Arabism should not require an identity card.

So why should I be waiting at those unreal borders?

And I recalled my grandfather's praise of Al- Jahiliyyag days.

When an Arab could roam Arab cities.

Carrying only his food and his Arabic language.

He started asking about my name and nationality.

And the reason for my sudden visit.

I answered him that my name was "unity".

And my nationality was Arab and my visit was historic.

He asked about my profession and if I had any criminal convictions.

I said: "I am an ordinary person

But I witnessed the assassination of nationalism".

He asked about my birthdate and which Hijri year it was.

I told him I was born on the same day humanity was (born).

He asked if I had any transmissible diseases

I said: "I had an angina, when my son asked me about

The meaning of Arab unity".

Then he asked me about my religion: Islam or Christianity.

I told him I worshiped God in all celestic religions.

He then returned my documents, my bag and identity card

And said: "Go back to where you came from

Since my country does not welcome freedom.

\section{Discussion and Analysis}

Darwish felt the pulse of Palestine in a very beautiful expressive poetry. He is the mirror of the Palestinian people. He created the national Palestinian identity that no other poets could achieve. When he was 22 , his famous poem "Identity Card", addressed to an Israeli policeman "Write down. I am Arab", became a rallying cry of defiance and protest. People protest to affirm their identity. The poet says he is still in the exile. "Exile is not a geographic state. I carry it everywhere as I carry my homeland". Identity for darwish has different concepts:, homeland, language, traditions, culture, nature, belonging, liberty ...etc. Darwish handles all these concepts sometimes directly and sometimes indirectly to express his concept of identity. Accordingly, how does Darwish express identity in his poetry? 


\subsection{Identity and Language}

Identity is constructed through a variety of symbolic resources particularly language. Marked identities are ideologically associated with marked language. Identity is rooted not only in genetics but also in heritable cultural forms: especially language which symbolizes and ironically embodies the distinctive cultural identity of an ethnic group. Language is often taken as the prototypical semiotic system, it is more complex than many other systems because it has social meaning as well as referential meaning. Such semiotic associations are created by a number of ways: practice, indexicality, ideology, and performance. See (Language and Identity—Mary Bucholtz and Kira Hall )

Language is a vital tool of communicating thoughts, ideas, feelings, relationships, friendships, cultural ties, and through which emotions are shaped and perceptions of reality are determined. (Whorf as cited in Kramesch). See Bucholtz \& Hall (1985, p. 374).

Language, as a fundamental resource for culture production, is also a fundamental resource for identity production. This assertion challenges the common understanding of language as a mirror reflecting one's culture and identity formation by providing a sense of cohesion and unity for it's speakers. Palestinians in Israel, for example perceive Arabic as one of the most salient markers of their Palestinian identity. Arabic is also viewed as a significant indication of their pan- Arabic identity. See Amara (2006, p. 4) and Amara \& Mar'i (1998). Most Palestinians in Israel speak Arabic as their first language, they use it at home and their towns and villages but they use Hebrew at work and in other setting. See Spolsky \& Shohamy (1999).

Language plays a special role in Darwish's quest for identity. When the man left Palestine, he travelled from one place to another, and as a result he began to make "a homeland of words" This indicates that he began to see his homeland Palestine within his language. See Masalha (2008) "Mahmoud Darwish is considered a savior of the Arab language" says Subhi Hadidi as cited in Saith Ashwani. (2005, p. 29).

\section{We Travel Like All People}

Ours is country of words: Talk. Talk

Let me rest on my road against a stone

Ours is country of words: Talk. Talk

Let me see an end to this journey

Throughout Darwish's work this question of identity in the face of displacement continues to be a primary one. This concern with identity, however, is not one that looks simply to reconnect a specific identity claim with corresponding borders, linguistic or geographic, but one that seeks to answer more abstract questions about developing an identity rooted in community as constructed through words, or rather, through what the words represent, Darwish says he is still in exile. "Exile is not a geographic state. I carry it everywhere as I carry my homeland". His home has become his language, "a country of words".

\section{A Rhyme for the Odes}

Who am I? This is a question that others ask, but has no answer.

I am my language.

I am an ode, two odes, ten.

This is my language

I am words' writ:

Be! Be my body!

No land on earth bears me. Only my

words bear me,

This is my language, a necklace of stars

around the necks

of my loved ones. They emigrated.

They carried the place and emigrated.

They carried time and emigrated.

Language for Darwish is home and self. It is outside of place and time, because with it "they carried the place...they carried the time". Darwish said: "Poems can't establish a state. But they can establish a 
metaphorical homeland in the minds of people. I think my poems have built some houses in the land scape. (Darwish, M. Interview “The politics of Poetry"). In his "Mural” Darwish writes:

\section{Mural}

Leave everything as it is,

\section{But bring my language back to life}

I don't want to return to anyone.

I don't want to return to my country

After this long absence,

I want to return to my language

In this remotest depth of the dove's cooing.

Darwish writes in his "I belong There" I have learned and dismantled all the words in order to draw from them a single word: Home. This statement reveals a better understanding of the relationship between words (language) and place (homeland). "Home" is universally significant. This word is not only addressed to Palestinian people, but to all displaced people all over the earth.

I come from there, and I return the sky

To its mother when it cries for her, and cry

For a cloud on its return

To recognize me. I have learned

All words befitting of blood's court to break

The rule; I have learned and

dismantled all the words

in order to draw from them

a single word: Home

In these poems, Darwish spelled out the role of the language in the formation of national identity. Language is portrayed as a home for homeless, the exiles, and the alienated. Arabic language is a paramount marker of Palestinians . Palestinian identity for Darwish cannot be separated from Arabic identity and language.

\subsection{Identity and Land}

The central theme in Darwish's Poetry is watan, or homeland. Most of Darwish's poems, particularly "Identity Card", "Passport", "To My Mother", "A Lover from Palestine", “On This Earth", "I Belong There", "Pride and Fury", "Palestine", "Diary of Palestinian Wound", "Perseverance" and "My Roots" among others embody directly or indirectly the interconnectedness between identity and land form an ecopostcolonial perspective.

\section{Leaves of Olives}

Perhaps like me you have no address

What's the worth of a man

Without a homeland,

Without an address?

In his "Lover from Palestine", Darwish metaphorically portrays his love for his homeland Palestine by symbolizing her as woman whom he eternally loves:

Your eyes are a thorn in my heart;

It stings me, yet I adore it

And protect it from the wind.

I thrust it deeper and deeper

Beyond darkness and pain,

So that its wound kindles the lights of lamps

And makes from my present days a future for her

Which is dearer to me than my soul.

Similarly, land (Palestine) for Darwish is his lady and he deserves life just because Palestine, his homeland, is his lady. 


\section{On This Earth}

We have on this earth Palestine what makes life worth living on this earth, the lady of earth

Mother of all beginning and ends

She was called Palestine and she is still called Palestine

My lady, because you are my lady I deserve life.

In his poem "To My Mother", Darwish indirectly portrays his homeland Palestine as his identity through some Palestinian emblems: bread, coffee, and touch as symbols of solidarity and belonging:

\section{I long for my mother's bread, And my mother's coffee, \\ And her touch}

Children memories grow up in me

Day after day

And I love my life

Because if I die

I will be embarrassed from the tears of my mother.

Darwish says: "The relation with mother is filled with symbols, because it could be associated with land, with continuity, with legitimacy (Interview with Mohammed Darwish, Najat Rahman, in Nassar and Rahman: 319).

In this poem, Darwish is expressing his closeness and interconnectedness with his homeland through referring to Palestine as his mother. He deliberately refers to his mother's bread, coffee, and touch because Arabs have their special way in making bread and coffee that cannot be served elsewhere in the same manner and taste.

The repetition of the refrain in his "Identity Card":

\section{Write Down}

\section{I am an Arab!}

forms a cry that embodies the connection between Palestinian identity and land on the one hand and between Palestinians and Arabs on the others. That means it inextricably links Palestinians with their land on the one hand and Arabs on the other hand. See Antoon (2008).

It can be asserted that Darwish concerns himself more and more with the origins of the Palestinian people and their inseparability from their land. This idea can be clearly expressed in his "My Roots":

\section{My Roots}

Were deeply entrenched before the birth of time

Before the opening of eras

Before the pines and the olive trees

And even before the grass grew

The metaphor used in this extract reflects the spontaneous overflow of a powerful sense of inseparability between Palestinians and their land. The expression "my roots were deeply entrenched" (borrowed from the world of plants) evokes the sense of rootedness between the poet and his homeland.

Related to land, Darwish embodies the place as another component of the Palestinian identity. Place for him is the city, the village, the field, the sea, all of which form the geography of the homeland, He describes the place to emphasize the historical, geographical and cultural entity of the Palestinians. For example the sea of Palestine is always present in his poetry.

\section{This sea is mine}

\section{This sea air is mine}

\subsection{Identity and Nature}

Gloftelty \& Fromm (1996) present ecocriticism as "the study of the relationship between humans and the natural world". That means ecocriticism takes interconnection between man and nature as its subject.

Homeland is a predominant theme in Darwish's poetry. Nature and environment are closely related to home and 
this is central to ecocriticism, the interconnections between man and nature. Darwish's poems, particularly those he wrote in the exile illustrate the ecopostcolonial perspective as we will see below. These poems about nature show how Darwish's identity as Palestinian cannot be separated from nature or physical environment. This indicates that identity and home are expressed through natural elements in Darwish's poetry. That is to say, home cannot be discussed in isolation from the context of environment.

Darwish uses the environment of his homeland as a base of the interconnectedness between identity and home. Darwish declared once (as cited in Celik, 2008, p. 275) that his poems do not deliver only images and metaphors of Palestinians but also convey landscapes, villages, and fields. He added, "I find myself looking at an olive tree, and as I am looking at it, it transforms itself before my eyes into a symbol of our home... If the olive trees knew the hands that planted them, their oil become tears" (Darwish, 2003, p. 3).

In his early poems, Darwish portrays how the ecological interrelationship between Palestinian people and their environment is represented by land through the aspects of nature. For example, in his "The Passport", Darwish portrays the interconnectedness between Palestinian identity and nature when he says:

$$
\text { Oh, Gentlemen, Prophets }
$$

Do not ask the trees for their names

Do not ask the valleys for their mother

From my forehead bursts the sward of light

And from my hand springs the water of the river

All the hearts of the people are my nationality

So take away my passport!

The elements of nature in the above lines are represented by "the trees", "the valleys", "light", and "the water of the river" as bud interconnectedness between Palestinians and their land.

Similarity, in his "Love from Palestine" nature plays an important role as main factor of identity formation. Darwish refers to specific places in Palestine including cities, villages, mountains, lakes, rivers...etc. Besides, he drew upon the indigenous fauna and flora, birds, flowers, plants, and gardens. All these objects remind Darwish of his homeland Palestine. In his "Earth Presses Against Us", he says:

Here we will die. Here, in the final passage.

Here or there, our blood will plant olive trees

The connection between Palestinians and their nature can be seen in his "The Perservance" when he says:

We will not be separated

The seas and the deserts are in front of us

The forests are behind us

Oh, my friend, take me.

How can we be separated?

\title{
3.4 Identity, and Culture, Traditions and Heritage
}

Brown (2007, p. 188) says that "culture is our continent, our collective identity" Brown added "culture may be defined as the ideas, customs, skills, arts and tools that characterize a given group of people in a given period of time". Larson \& Smalley (1972, p. 39) described culture as a "blueprint" that guides the behaviors of people in a community and is incubated in family life. According to Matsumoto (2008, p. 24), culture is a dynamic system of rules, explicit and implicit, established by groups in order to insure their survival, involving attitudes, values, beliefs, norms, and behaviors shared by a group of people.

Darwish in his poetry portrays the relationship between the Palestinian identity and the Palestinian culture, traditions, and heritage. His poem: "Identity Card" illustrates the interconnection between Palestinians and their traditions:

\author{
My father is from the family of the plough \\ Not from a noble line. \\ My grandfather was a peasant \\ Without nobility genealogy. \\ My house is a crop- warden's shack.
}


The expression such as "plough" "peasant" and "a crop-warden's shack" are signs of the relationship between the poet and land on the one hand and between nature and culture on the other i.e., between farming and land.

Darwish invokes culture, customs and traditions, family ties and some other indigenous or domestic emblems from his heritage to which Palestinians could resort for stability and steadfastness. Such symbolic objects as his mother's bread, her coffee, family, olive and citrus trees, rocks, mountains, trees, sea, etc. were used as signifiers of cultural and national identity.

In his poem "To My Mother" Darwish is expressing his zeal for closeness with his homeland by referring to Palestine as his mother. He deliberately refers to his mother's bread, coffee and touch because Arabs have their special ways (culture and traditions) in making bread and coffee that can not be served elsewhere in the same manner and taste. Besides, coffee is a symbol of home. Traditionally, Arabs coffee is linked with marriages and funeral ceremonies, and this is how coffee becomes a symbol of solidarity and belonging.

I long for my mother's bread, My mother's coffee,

Her touch

Childhood memories grow up in me,

Day after day

And I love my life

Because if I die

I will be embarrassed from the tears of my mother.

In the second stanza Darwish says:

If I come back one day

Take me as a veil to your eyelashes

Cover my bones with the grass

The image "take me as a veil to your eyelashes" is depicted from the Arab Muslim culture in which women cover their faces as a commitment to make them unknown to foreigners. Moreover, the use of "veil" evokes the sense of the poet's closeness to his homeland Palestine, and the sense of hidden feelings that Palestinians have towards their land. In the third stanza:

\author{
If I come back \\ Use me as wood to feed your fire \\ As the clothesline on the roof of your house \\ Without your blessing \\ I am too weak to stand.
}

Darwish is expressing the images of simplicity of the Palestinian way of life as they still use wood to make fire and clothesline on the roofs of their houses.

\title{
3.5 Identity and Exile
}

Palestinians live in the exile even in their homeland. Khalidi $(2010$, p. 1) argues that Palestinians in their homeland suffer a lot at borders and checkpoints. This means Palestinians are discriminated at these borders and checkpoints and this reminds them of their identity and their land. Khalildi echoes Darwish's insights when he asserts that "the quintessential Palestinian experience, which illustrate some of the most basic issues raised by Palestinian identity, takes place at a border, an airport, a checkpoint: in short, at any one of these many modern barriers where identities are checked and verified. What happens to Palestinians at these crossing points brings home to them and how much they share in common as people. For it is at these borders and barriers that six million Palestinians are singled out as for special treatment, and are forcefully reminded of their identity: of whom they are, and why they are different from others".

Shihab as cited in Mahmoud Darwish: "The Palestinian Poet of Exile", says that "Darwish is the essential breath of the Palestinian people, the eloquent witness of exile and belonging,..." It is pointed out after the death of Darwish (the 9th of August, 2008) that "Mahmoud does not belong to a family or a town but to all Palestinians, and he should be buried in a place where all Palestinians can come and visit him".

In his poem "Risala min Al- Manfa" "Letter from Exile", Darwish who became homeless at the age of six faced difficult problems in his exile is trying to regain his identity and establish connection to his homeland. These problems are expressed in the following lines: 


\section{All I have in my exile \\ Is a haversack containing a stale loaf, my yearning, \\ And a notebook which somehow lightens my burdens \\ Perhaps like me you have no address \\ What's the worth of man \\ Without a homeland \\ Without an address?}

In these lines the poet is expressing his uprooting and separation from his homeland. This means that he is suffering the anguish of losing his identity and homeland.

Similarity, in his "Lover from Palestine" Darwish compares himself to a sparrow:

Your words were a song

I tried singing

But winter replaced the spring.

Your words, like the sparrow, flew away

After you

I saw you last at the airport

A lonely traveler without luggage

I ran to you like an orphan, a child

Seeking answers in ancestral wisdom:

How could the green orchard be imprisoned

Exile banished to a port

And still remain green

The sparrow, a Palestinian bird who leaves its place for some time and comes back, symbolizes resistance of the exiled Palestinian people who are forced to leave their homeland but they will come back one day to their land like a sparrow. This indicates that if Palestinians do not live in their land, their land lives in them. This also means that sparrow is a symbol of Palestinians connections to their land.

Similarly, in his "An Eulogy of High Shadow" in which Darwish portrays his home as a bag he is carrying in his exile when he says:

$$
\begin{aligned}
& \text { My homeland is a bag } \\
& \text { It is my bed at night } \\
& \text { My homeland is a bag } \\
& \text { I carry it on my shield }
\end{aligned}
$$

The words "bag" and "bed" are symbols of interconnections between the poet and his homeland that can not be separated although the exile. His "bag" and his "bed" accompany him wherever he goes. The image of "I carry it on my shield" indicates his constant effort, the impact of homeland, and the mental influence of being alienated from his homeland.

Darwish's “A Diary of a Palestinians Wound" is also one of his exile poems in which he says:

\section{We and our land are one flesh and bone We are its salt and water}

We are its wound, but a wound that fights.

Darwish depicts the images "one flesh and bone", "we are its salt and water", and "we are its wound", "but a wound that fights" in which he evokes the sense of a deep interconnections between Palestinians and their homeland inside and outside Palestine because "flesh" can not be removed from the "bone" and this image symbolizes the poet's suffering from being far away from his land and a sense of homelessness in the exile. Similarly, the image "salt and water" two important ingredients of our bodies that are impossible to separate conjures the sense of rootedness although the poet lives far from his homeland.

In this poem "My Father" Darwish gives a very passionate image of a Palestinian father who advises his son not to leave his homeland: 


\section{My father once said: \\ He who has no homeland \\ Has no grave on earth. \\ And forbade me to leave!}

The father in this poem is advising his son never to leave his homeland because he will never find a grave on earth but in Palestine. This image also shows a deep interconnection between Palestinians and their land.

Another poem which addressed the theme of exile, homelessness, and alienation is "Oh My Father, I am Yusuf":

Oh father, my brothers neither love me nor want me in their midst.

They assault me and cast stones and words at me.

They want me to die so they can eulogize me.

They closed the door of your house and left me outside.

They expelled me from the field.

Oh my father, they poisoned my grapes.

They destroyed my toys.

When the gentle wind played with my hair, they were jealous.

They flamed up with rage against me and you.

What did I deprive them of, Oh my father?

The butterflies stopped on my shoulder.

The bird hovered over my hand.

What have I done, Oh my father?

Why me?

You named me Yusuf and they threw me into the well.

They accused the wolf.

The wolf is more merciful than my brothers.

Oh, my father.

Did I wrong anyone when I said that

I saw eleven stars and the sun and the moon

Saw them kneeling before me?

This poem comes to express the pains and sufferings of Darwish in the exile, far away from home. The words used by the poet indicate the deliberate actions that cause suffering of Palestinians, because Israelis make them live strangers inside and outside their country.

The Qur'anic story of Yusuf and his brothers depicts the relationship of hatred and discrimination between the Palestinians and the Israelis. Although they descended from the same father Ibrahim (Abraham) and so they are supposed to be brothers, they hate each other, divided by deep conflict and racial discrimination. Darwish depicts Israeli people as his brothers, but they refuse to live with Palestinians as their brothers. They have practiced different aspects of oppressions and discrimination as Yusuf's brothers did.

\section{Dimensions of Palestinian Identity}

The Palestinian identity can be described as a three — dimensional one: Palestinian, national, and human.

\subsection{Palestinian Dimension}

The Palestinian identity has its own characteristics which keep its peculiarity taken from the history, geography, culture, and nature of Palestinian people. It is a unique identity:

\section{Lover from Palestine}

Palestinian are your name and tattoo.

Palestinian are your thoughts and dreams.

Palestinian are your mantilla, your body and your feet.

Palestinian are your words and silence.

Palestinian are your voice.

Palestinian are your birth and death. 
All people have their own peculiarities, their own features, and their own characteristics which differentiate them from others:

\title{
My friend
}

The Nile will not flow into the Volga,

Nor the Congo or the Jordan into the Euphrates.

Each river has its source, its course, its life.

My friend, our land is not barren.

Each land has its time for being born.

Each dawn a date with a rebel.

\subsection{National (Arabic) Dimension}

The origin of the Palestinian identity is Arabic, as it is very similar to other Arabic identities because all Arabs share the same language, history, geography, values, and inheritance. Darwish's poem "Identity Card" portrays his national (Arabic) identity:

\author{
Record! \\ I am an Arab \\ And my identity card is number fifty thousand \\ I have eight children \\ And the ninth is coming after a summer \\ Will you be angry? \\ Record! \\ I am an Arab \\ I have a name without a title \\ Patient in a country \\ Where people are enraged.
}

\subsection{Human Dimension}

Darwish rejected anti-Semitism, saying: "The Accusation is that I hate Jews. It is not comfortable that they show me as a devil and an enemy of Israel. I am not a lover of Israel, of course. I have no reason to be. But I don't hate Jews. See (Mahmoud Darwish: The Palestinian Poet of the Exile).

Darwish goes beyond his Palestinian and national (Arabic) identities to human identity. The concept of otherness does not exist in Darwish's poetry. In his "Passport" and "Identity Card" Darwish expresses the Palestinian tolerance and coexistence. Although Palestinians suffer a lot, they do not hate others. They do not resist the Jews because they are Jews, but because they occupied their land.

Oh, gentlemen, Prophets,

Don't ask the trees for their names

Don't ask the valleys who their mother is

From my forehead bursts the sward of light And from my hand springs the water of the river

All the hearts of the people are my identity

So take away my passport!

Besides, no hatred exists in Darwish poetry but rather tolerance, but he is forced to resist occupation:

Identity card

Record on the top of the first page:

I do not hate people

Nor do I encroach

But if I become hungry

The usurper's flesh will be my food

Beware..

Beware..

Of my hunger

And my anger! 


\section{Findings and Conclusion}

Darwish uses his poetry to quest and express his sense of identity throughout various phases as a Palestinian, as an Arab, and as a human. As a Palestinian and as an Arab, he depicts his sense of Palestinian and Arab identity as belonging to homeland. He portrays this sense as homeland, language, culture, traditions, values, history, geography, roots, and environment because all Arabs share the sense common language, the same culture, the same traditions, values, and heritage, the same roots, the same culture, the same history and geography.

Put it differently, Darwish lived most of his life in the exile, but never forgot that he belongs to Palestine, his homeland, his mother tongue, his traditions and heritage, his culture, his roots and ancestors, and nature.

Darwish uses nature, the unique Palestinian and Arabic fauna and flora to extend his interconnectedness between identity and land to highlight the strong relationship between man and nature. That is to say, this study also attempts to explore Darwish's application of environment to reflect his perception of home through utilization of nature of his homeland (central field of postcolonial ecocriticism).

Finally, Darwish envisioned a multifaceted identity that would live in peaceful coexistence with the Jews.

\section{References}

Amara, M. (2006). The Vitality of Arabic Language in Israel from a Sociolinguistic Perspective. Adalah's Newsletter, 29, 1-11.

Amara, M., \& Mar'i, A. (1999). Issues in the Policy of Language Education in Arab Schools in Israel. Giv'at Haviva Institute: Jewish-Arab Centre for Peace (Hebrew).

Antoon, S. (2008). In the Presence of Darwish. The Nation. Retrieved from http://www.thenation.com/article/presence-darwish

Ashcroft, B. et al. (2000). Key Concepts in Post_Colonial Studies (2nd ed.). London and New York: Routledge.

Bloom, W. (1990). Personal Identity, National identity, and International Relations. Cambridge: Cambridge University Press. https://doi.org/10.1017/CBO9780511558955

Brown, D. (2007). Principles of Language Learning and Teaching (2nd ed.). New Jersey: Prentice-Hall, Inc.

Bucholtz, M., \& Hall, K. (1985). Language and Identity. In A. D. Alessandro (Ed.), A Companion to Linguistic Anthropology.

Bucholtz, M., \& Hall, K. (2005). Language and Identity. In A. D. Alessandro (Ed.), A Companion to Linguistic Anthropology (pp. 369-394). Oxford, UK: Blackwell Publishing Ltd. https://doi.org/10.1002/9780470996522.ch16

Celik, A. (2008). Alternative History, Expanding Identity: Myths Reconsidered in Mahmoud Darwish's Poetry. In H. Nassar \& N. Rahman (Eds.), Mahmoud Darwish: Exile Poet (pp. 273-291). Northampton: Olive Branch Press.

Darwish, M. (2003). Unfortunately, It was Paradise: Selected Poems (Trans. Munir Akash \& Carolyn Forche' Berkely). Los Angeles, London: University of California Press.

Darwish, M. (2005). Interview "The Politics of Poetry” Newsweek Gale. University of Massachusetts, Boston.

Deng, M. (1995). War of Vision: Conflict of Identity in the Sudan. Washington, DC: Brooking.

Glotfelty, C., \& Fromm, H. (1996). Ecocriticism Reader. Athens and London: The University of Georgia Press.

Hogg, M., \& Dominic, A. (1988). Social Identification. A Social Psychology of Intergroup Relations and Group Process. London: Routledge.

Hopf, T. (1998). The Promise of Constructivism in International Relation Theory. International Security, 23, 171-200. https://doi.org/10.1162/isec.23.1.171

Karamsch, C. (2005). Language Thought and Culture. In A. Davies \& C. Elder (Eds.), The Handbook of Applied Linguistics (pp. 235-261). New York: John Wiley and Sons.

Khalidi, R. (2010). Palestinian Identity: Construction of Modern National Consciousness. New York: Coumbia University Press.

Larson, D. N., \& Smalley, W. A. (1972). Becoming Bilingual. A Guide to Language Learning. New Canaan. C. N: Practical Anthropology.

Masalha, S. (2008). Mahmoud Darwish Made a Homeland of Words. Retrieved from 
salmaghari-en.blogspot.com

Matsumoto, D. (2008). Cultural and Emotional Expression Understanding Culture: Theory, Research and Applications.

Oppenheimer, A. (n. d.). Principle of Identity Preservation. Retrieved from http://answers.com/topic/principle-of-identity- preservation

Rahman, N. (n. d.). Interview with Mahmoud Darwish: On the Possibilty of Poetry at a Time of Siege (pp. 319-326). In Nassar \& Rahman (Eds.).

Saith, A. (2005). Mahmoud Darwish: Hope as Home in the Eye of the Storm. ISIM Review, 15(Spring), $28-29$.

Shihab, N., \& Mahmoud, D. (n. d.). The Palestinian Poet of Exile (The Hyper Text). Retrieved http://www.thehypertexts.com/mahmoud

Spolsky, B., \& Shohamy, E. (1999). Language in Israel Society and Education. International Journal of the Sociology of Language, 137, 93-114. https://doi.org/10.1515/ijsl.1999.137.93

Suleiman, Y. (2003). The Arabic Language and National Identity. Edinburgh: Edinburgh University Press.

Wikipedia. Identity Formation. Retrieved from http://en.wikipedia.org/wiki/identity-farmation

\section{Copyrights}

Copyright for this article is retained by the author, with first publication rights granted to the journal.

This is an open-access article distributed under the terms and conditions of the Creative Commons Attribution license (http://creativecommons.org/licenses/by/4.0/). 